\title{
Authority Delegation and Leadership Succession in Nigeria Electricity Distribution Company
}

\author{
Oti Nkiruka ${ }^{1}$, Ezenwakwelu Charity ${ }^{1, ~}$, Nwanmuoh Emmanuel ${ }^{2}$ \\ ${ }^{1}$ Department of Management, Faculty of Business Administration, University of Nigeria, Enugu Campus, Nigeria \\ ${ }^{2}$ Department of Marketing, Faculty of Business Administration, University of Nigeria, Enugu Campus, Nigeria
}

\section{Email address:}

nkiruemekaoti@gmail.com (O. Nkiruka),Charityezenwa80@yahoo.com (E. Charity), emmanuel.nwanmuoh@unn.edu.ng (N. Emmanuel) ${ }^{*}$ Corresponding author

\section{To cite this article:}

Oti Nkiruka, Ezenwakwelu Charity, Nwanmuoh Emmanuel. Authority Delegation and Leadership Succession in Nigeria Electricity Distribution Company. Science Journal of Business and Management. Vol. 9, No. 2, 2021, pp. 74-80. doi: 10.11648/j.sjbm.20210902.14

Received: May 4, 2021; Accepted: May 24, 2021; Published: June 7, 2021

\begin{abstract}
The paper conducted investigation on authority delegation and leadership succession in Nigerian Electricity Distribution Company. Delegation is the process of assigning to the subordinate responsibility for decisions which were formally made by the manager. Delegating authority provides a means for evaluation of employee skills and major attributes, such as leadership qualities, reliability and creativity. Authority delegation aids implementation and succession plan of an organization management. Delegation provides opportunity for training and development, and of testing the subordinate's suitability for leadership and promotion. The study examined the relationship between authority delegation and employee understudy, assessed the extent of the relationship between authority delegation and management succession and determined the effect of authority delegation on leadership accountability. The target population included managers, supervisors and senior staff of Enugu Electricity Distribution Company headquarters, and eighteen district offices in SouthEast, Nigeria. Findings revealed that a positive relationship exists between authority delegation and employee understudy; A Positive relationship also exists between authority delegation and management succession; and authority delegation positively affected leadership accountability. The study concluded that authority delegation is crucial for management and leadership succession. The study deliberately proposed that leadership succession programmes should be fused into the training plan of companies to prevent leadership vacuum. Managers need to acquire delegation skills to enable the leader manage time effectively.
\end{abstract}

Keywords: Authority Delegation, Responsibility, Accountability, Understudy, Leadership Succession, Leadership Vacuum, Professional Growth

\section{Introduction}

Delegation refers to senior managers' willingness to assign authorities to subordinates to perform certain tasks with empowerment to access the required resources Akinfolarin, [2] Delegation constitutes a vital part of leadership process used by managers Sengul, Gimeno \& Dial [24]. The more delegation is practiced in a firm, the less the practice of micromanagement White, [25]. Delegation is the organizational process of transfer of authority from a supervisor to a subordinate Koontz and Weihrich, [18].

Authority delegation empowers a subordinate to make commitments, use money, and make decisions about the duties delegated to him. No organization can work effectively, without delegation. Delegation stems from the fact that one entity alone cannot perform all of an organization's obligations effectively. It is the transfer of responsibility for the execution of specific tasks and decision-making in a general or specific field of managerial activity to others Koontz and O'Donnell, [19].

Delegation involves the assignment of authority to a subordinate to carry out specific activities. The person who delegated authority remains accountable for the outcome of the delegated work. Delegation is a two-way process: it saves time, develops people, prepares a successor and motivates both the subordinate and the manager. However, poor delegation causes frustration, demotivates and fails to accomplish the task. Management and leadership succession is supported by effective delegation. The more reliable and 
experienced the subordinate is, then, the more authority that is given to him. When the task becomes critical, there should be caution in extending authority to another person. Delegation of authority makes an employee feel respected, trusted and motivated. Delegating authority is a means that makes employees feel contributing to the organisation's progress. Delegation is helpful in succession planning, personal development and leadership effectiveness. Sufficient delegation is necessary for management and leadership succession. (BusinessBalls.com).

Delegating authority provides a means for evaluation of employee skills and major attributes, such as leadership qualities, reliability and creativity. Delegating authority plays an important role that grant workers the latitude to develop their innovative leadership ideas and problem solving strategies. Delegated authority allows the superior to share responsibility with his subordinates. When one delegate, three major factors are implicit: there is an assignment of responsibility, there is a delegation of authority and there is a creation of accountability. Thus delegation involves assigning to the subordinate responsibility for decisions which were formally made by the manager Yukl \& Fu, [26].

This paper seeks to examine the relationship between authority delegation and employee understudy, assess the extent of the relationship between authority delegation and management succession and determine the effect of authority delegation on leadership accountability in Enugu Electricity Distribution Company.

\section{Conceptual Review}

\subsection{Authority Delegation and Employee Understudy}

The principle of delegation is the centre of all processes in formal organisations. Delegation, involves authority and responsibility. Responsibility must be supported by authority and by the power to influence the area of performance for which the subordinate is to be held responsible. The problem of delegation when authority is delegated could be failure to provide the needed information and other resources that will achieve the result expected or the problem of delegation could be failure to delegate sufficient authority that will enable subordinates to fulfill their responsibilities. To hold subordinates responsible for certain area of performance without also conferring on them the necessary authority within the structure of the organisation to take action and make decisions within the limits of that responsibility is an abuse of delegation Mullins, [21]. Delegation of authority is the process by which managers assign to subordinates the right for making ssdecision by acting in certain situations. Delegation involves conferring of a specified authority by a higher authority. It involves a dual responsibility: The person to whom the authority is delegated becomes responsible to the superior for doing the job, while the superior remains responsible for getting the job done. Understudy involves employee working as a subordinate partner with a boss so that in the event of the absence, retirement, or death of the boss, the personnel can assume the full responsibilities for duties of the job. Ezigbo, [9].

Previous researchers including Mullins, [21] and Ezigbo, [9] confirm that authority delegation supports employee understudy. Thus, hypothesis 1 is proposed: authority delegation has positive relationship with employee understudy

\subsection{Authority Delegation and Management Succession}

Authority delegation aids implementation and succession plan of an organization management. Delegation provides opportunity for training and development, and of testing the subordinate's suitability for leadership and promotion Mullins, [21]. Succession planning is the process of identifying and developing new leaders to replace old leaders when they leave, retire or die. It provides capable employees that are prepared to assume the roles as they become available. A leadership succession strategy is the process that identifies and develops employees with the potential to fill key leadership positions in the company. Leadership succession is a critical strategic issue for getting and retaining talented leaders.

Mullins, [21] describes management succession as the plan or process by which new potential employees are identified and developed to replace existing leaders who will be transitioning out of their current responsibilities because of retirement, disability, termination, or death.

Management Succession as the process of identifying one or more successors for key positions and preparing them for expanded organisational responsibilities through job assignments and other developmental activities. Management succession helps to build a deep capacity for leadership. Not only is there leadership bench strength and a full leadership pipeline, there is also a highly developed workforce that is adaptable and attuned to the challenges and opportunities that are presented in their work. Management Succession can also help in the recruitment and retention of the talent that is needed to be competitive in the global economy. Most employees today want more from their work than a paycheck. The opportunity to grow and develop on the job is a factor that can attract and retain talent. Succession planning improves the morale, loyalty and commitment of the employee and helps the organisation to manage and retain their talented staff Bolander, Werr \& Asplund, [5]. Management succession may entail hiring a successor from outside the organization Zhang \& Rajagopalan, [28]. Moreso, a successor can come from the previous era and that type of succession is known as Boomerang Dalton \& Dalton, [7]. Succession is the test of success in business. This is shown if the business grows large and is in good condition, succession promotes continuity (Gersick et al, 1999).

Charan, Drotter \& Noel [6] Posit that succession planning is sustaining the organization by building high performance people to fill the pipe line to ensure that every leadership level has an abundance of high performers to draw from the present and in the future. Garman \& Glawe [11] see succession planning as management pipeline that accelerates management performance over a period of time. Succession planning is an organized process which comprises of identification and preparation of potential successor to assume new role Osibanjo, Abiodun \& 
Obamiro [22]. To have a sustainable and dynamic succession plan, there is need to examine the firm's strategy and policy that identify the required qualifications of the successor Kartz, [16]. Succession planning is a subjective approach whereby an individual employee is prepared to replace the incumbent when his position becomes vacant, which rarely happens and probably indefinite Landeta, Barrutia \& Hoyos, [20]. Schall [23] identify the barriers against succession planning as leader's reluctance to take on succession planning task, the assumption of the leader that succession planning is beyond their work scope, lack of understanding about succession planning and inability to handle succession planning in a changing political environment.

In succession process, issues related to selection procedures are of great concern Zald, [27]. The most critical decisions a board makes which often introduce a high degree of uncertainty into the organization is the chief executive officer (CEO) selection (Vancil, 1987). Transition from one CEO to another is usually difficult as the organization shifts from a known to an unknown leader which brings significant organizational consequences Giambatista, Rowe \& Riaz [12] and Kesner \& Sebora [17]. Previous researchers affirm that a direct relationship exist between authority delegation and management succession. Thus, hypothesis 2 is proposed: Positive relationship exists between authority delegation and management succession

\subsection{Authority Delegation and Leadership Accountability}

Authority delegation and accountability relationship entails that the manager would play numerous roles. Also, as far as the manager is held accountable for outputs of the subordinates, he or she is expected to play a leadership role. Leadership involves assigning tasks, setting the context for the assigned tasks, and communicating the expected results and deadlines for the tasks. However, leadership involves supporting subordinates by providing resources to enable them get the job done right by coaching and mentoring. The manager in a delegationaccountability relationship plays the three roles of controlling, directing, and supporting the subordinates. Drucker, [8]; Jaques,
[4] Accountability refers to the expectation that subordinates will accept credit or blame for the results of their work. Leaders provide guidelines with which responsibilities are to be carried out. Subordinates are hereby accountable for performance within these limits. Accountability flows bottom up Ezigbo, [9]. Previous researchers confirm that authority delegation has positive effect on leadership accountability. Thus, hypothesis 3 is proposed: authority delegation positively affects leadership accountability.

\subsection{Delegation Flowchart}

Define the Task: The manager should define the task and confirm that it is suitable to be delegated.

Select the Individual or Team for Delegation: The individual or team selected should be fit to perform the task.

Assess Ability and Training Needs: The manager should examine the ability of the individual or team. To determine if the individual or team requires training (arrange for training, if yes and explain the procedure for the task, if no).

State Required Results: The manager should inform the individual or team the standard expected to accomplish the task and how it should be measured.

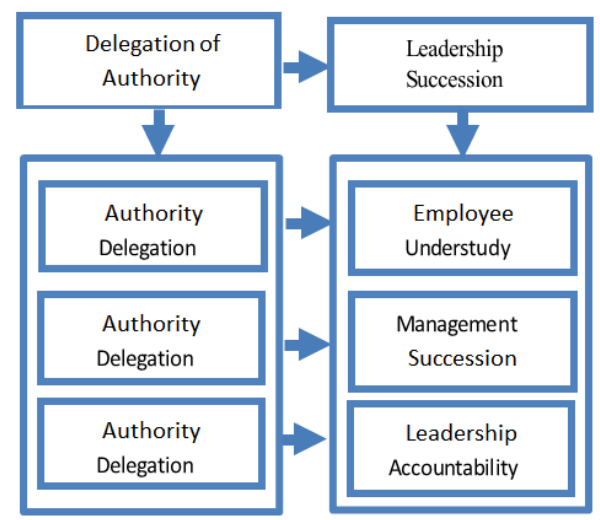

Figure 1. Conceptual Model of Authority Delegation and Leadership Succession.

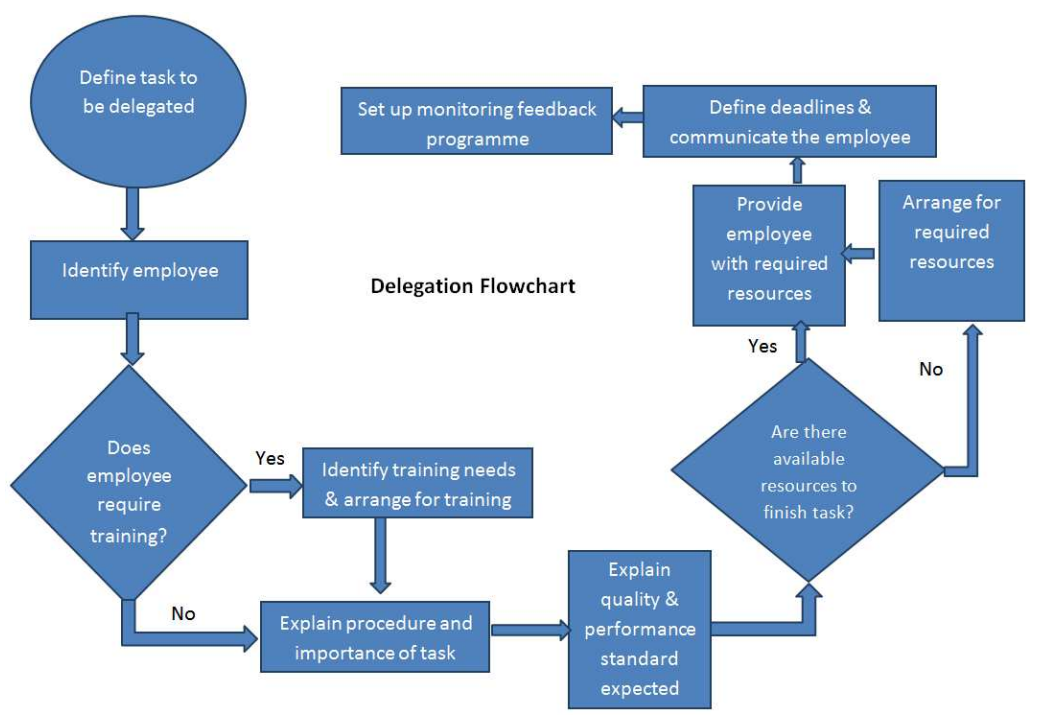

Figure 2. Steps to Successful Delegation. 
Consider Resources Required: The manager should discuss and agree what is required to get the job done (people, materials, location, equipment, money, etc). The manager should also provide the individual or team with the required resources, if yes (identify the training needs and arrange for training) and if no (explain the procedure and importance of the task).

Define Deadlines: The manager should define deadlines for the task and inform the individual or team for task completion.

Monitor Feedback: The manager should monitor the results from the task delegated, identify the deviations, insist on corrective action and also make commendation for meeting the standard.

\section{Methodology}

\subsection{Research Design}

The survey research design was adopted in this study. The survey is usually used for descriptive and exploratory research. The survey design gathers quantitative data that would be analysed with descriptive and inferential statistics. The survey design involves the use of questionnaire which is administered to a sample Ezenwakwelu, Ejim \& Adeoye, [10] The study was conducted through administration of a structured questionnaire which was designed on Likert scale format. The questionnaire was written in a simple language that reduces ambiguity. Secondary data were obtained from books, journals and internet.

\subsection{Sampling}

The target population consists of managers, supervisors and senior staff of Electricity Distribution Company (EEDC) headquarters, Enugu and eighteen district offices in SouthEast, Nigeria. EEDC was purposely selected to be used for this study due to the nature of the services it renders to the public which requires continuous supply and of which delegation of authority supports to ensure adequate production and supply. The population was 1843 from which the sample of 553 was obtained. There are 553 copies (96\%) of the questionnaire returned and 20 copies (4\%) of the questionnaire not returned. Data were presented in tables and the corresponding values in percentages. The sampled data were analysed by spearman's Bivariate Rank Correlation coefficient and ordinal logistic regression at five percent $(5 \%)$ level of significance. Opinion of experts from the academia were sought to ensure face and content validity of the instrument. Hypotheses one and two were tested with spearman bivariate rank correlation coefficient while hypothesis three was tested by ordinal logistic regression through the application of (SPSS v. 20).

\section{Analysis of the Questionnaire}

Table 1. The relationship between authority delegation and employee understudy.

\begin{tabular}{|c|c|c|c|c|c|c|c|}
\hline $\mathbf{S} / \mathbf{N}$ & Questionnaire items & $\mathbf{A}$ & SA & D & SD & $\mathbf{U}$ & Total \\
\hline 1 & Your manager involves subordinates in decision that concern them. & 216 & 294 & 10 & 8 & 5 & 533 \\
\hline 2 & Subordinates are trained to acquire leadership skills & 200 & 180 & 33 & 100 & 20 & 533 \\
\hline 3 & Manager assigns subordinates to represent them when they are not available. & 148 & 135 & 113 & 103 & 34 & 533 \\
\hline \multirow[t]{2}{*}{4} & Subordinates are willing to accept delegated authority & 250 & 219 & 30 & 19 & 15 & 533 \\
\hline & Grand Total/ Percentage & \multicolumn{2}{|c|}{$1,642(77 \%)$} & \multicolumn{2}{|c|}{$416(20 \%)$} & $74(3 \%)$ & 2,132 \\
\hline
\end{tabular}

Source: Field, Survey, 2019

Table 1 reveals that $1,642(77 \%)$ of the respondents agree that authority delegation has a relationship with employee understudy. Thus, $416(20 \%)$ of the respondents disagree while $74(3 \%)$ of the respondents were undecided.

$\mathrm{H}_{1}$ Authority delegation has positive relationship with employee understudy.

Table 2. Correlations.

\begin{tabular}{llll}
\hline & & AUTHODEL & Employee \\
\hline AUTHODEL & Spearman's rho & 1 & $.893^{*}$ \\
& Sig. (1-tailed) &. & .001 \\
Employee & $\mathrm{N}$ & 533 & 533 \\
& Spearman's rho & $.893^{*}$ & 1 \\
& Sig. (1-tailed) & .001 &. \\
& $\mathrm{~N}$ & 533 & 533 \\
\hline
\end{tabular}

*. Correlation is significant at the 0.05 level (1-tailed). AUTHODEL $=$ Authority Delegation

\section{Interpretation of Result}

The Spearman correlation coefficient reveals a positive relationship between authority delegation and employee understudy. It also indicates a significant relationship between the two variables $\mathrm{r}$

$(533)=.893^{*} ; \mathrm{p}=0.001<0.05$. Therefore, the alternate hypothesis which states that authority delegation has positive relationship with employee understudy is hereby accepted 
and the null hypothesis rejected.

Table 3. The extent of the relationship between authority delegation and management succession.

\begin{tabular}{|c|c|c|c|c|c|c|c|}
\hline $\mathbf{S} / \mathbf{N}$ & Options & $\overline{\mathbf{A}}$ & SA & D & SD & $\mathbf{U}$ & Total \\
\hline 1 & Authority delegation facilitates management succession. & 350 & 183 & 0 & 0 & 0 & 533 \\
\hline 2 & Authority delegation prepares subordinates for management succession. & 166 & 144 & 96 & 94 & 33 & 533 \\
\hline 3 & Effective management succession hinges on authority delegation. & 325 & 202 & 1 & 2 & 3 & 533 \\
\hline \multirow[t]{2}{*}{4} & Authority delegation relates with management succession. & 122 & 113 & 132 & 123 & 43 & 533 \\
\hline & Grand Total/ Percentage & \multicolumn{2}{|c|}{$1,605(75 \%)$} & \multicolumn{2}{|c|}{$448(21 \%)$} & $79(4 \%)$ & 2,132 \\
\hline
\end{tabular}

Source: Field Survey, 2019

Table 3 reveals that $1605(75 \%)$ of the respondents agree that authority delegation relates with management succession. Thus, $448(21 \%)$ of the respondents disagree while $79(4 \%)$ of the respondents are undecided.

$\mathrm{H}_{2}$ Positive and significant relationship exist between authority delegation and management succession

Table 4. Correlations.

\begin{tabular}{llll}
\hline & & AUTHODEL & Leadsucc \\
\hline AUTHODEL & Spearman's rho & 1 & $.851^{*}$ \\
& Sig. (1-tailed) &. & .024 \\
\multirow{4}{*}{ Leadsucc } & N & 533 & 533 \\
& Spearman's rho & $.851^{*}$ & 1 \\
& Sig. (1-tailed) & .024 &. \\
& $\mathrm{~N}$ & 533 & 533 \\
\hline
\end{tabular}

*. Correlation is significant at the 0.05 level (1-tailed).

AUTHODEL $=$ Authority Delegation, Leadsucc $=$ Management succession

Interpretation of Result

The Spearman's correlation result reveals that authority delegation relates with management succession. It also indicates a significant relationship between the two variables $\mathrm{r}(533)=.851^{*} ; \mathrm{p}=0.001<0.05$. Therefore, the alternate hypothesis which states that positive and significant relationship exist between authority delegation and management succession is hereby accepted and the null hypothesis rejected.

Table 5. The effect of authority delegation on leadership accountability.

\begin{tabular}{|c|c|c|c|c|c|c|c|}
\hline $\mathbf{S} / \mathbf{N}$ & Options & $\mathbf{A}$ & SA & D & SD & $\mathbf{U}$ & Total \\
\hline 1 & Delegation of authority requires responsibility and accountability. & 321 & 212 & 0 & 0 & 0 & 533 \\
\hline 2 & Subordinates are accountable to the manager when authority is delegated & 250 & 165 & 41 & 45 & 32 & 533 \\
\hline 3 & Delegation of authority is successful when there is room for accountability. & 155 & 100 & 102 & 96 & 80 & 533 \\
\hline \multirow[t]{2}{*}{4} & Effective delegation relies on Accountability & 155 & 136 & 102 & 110 & 30 & 533 \\
\hline & Grand Total/ Percentage & \multicolumn{2}{|c|}{$1,494(70 \%)$} & \multicolumn{2}{|c|}{$496(23 \%)$} & $142(7 \%)$ & 2,132 \\
\hline
\end{tabular}

Source: Field Survey, 2019.

Table 5 reveals that $1,494(70 \%)$ of the respondents agree that authority delegation relies on accountability. Thus, 496 (23\%) of the respondents disagree while 142 (7\%) of the respondents are undecided.

$\mathrm{H}_{3}$ : Authority delegation positively affects leadership accountability

Table 6. Parameter Estimates.

\begin{tabular}{lllllllll}
\hline & \multirow{2}{*}{ Estimate } & \multirow{2}{*}{ Std. Error } & \multirow{2}{*}{ Wald } & \multirow{2}{*}{ df } & \multirow{2}{*}{ Sig. } & \multicolumn{2}{c}{ 95\% Confidence Interval } \\
\cline { 6 - 9 } & & & & & Lower Bound & Upper Bound \\
\hline Threshold & {$[$ AUTHODEL $=54]$} & 9.821 & 13.115 & 7.256 & 1 & .000 & 9.821 & 11.007 \\
Location & {$[$ Leadaccount $=305$} & 5.006 & 10.207 & 3.033 & 1 & .008 & 5.006 & 6.454 \\
\hline
\end{tabular}

Link function: Logit.

The result shows that authority delegation has positive effect on leadership accountability. With an increase in the probability of increased leadership accountability at an odds ratio of $5.006(95 \% \mathrm{CI},=5.006$ to 6.454$)$, Wald $\chi^{2}(1)=$ $3.033, \mathrm{p}=0.008<0.05$. Therefore, the alternate hypothesis which states that authority delegation positively affects leadership accountability is hereby accepted and the null hypothesis rejected.

\section{Discussion of Results}

Spearman's correlation coefficient was used to test the relationship between authority delegation and employee understudy. The result revealed that authority delegation has positive relationship with employee understudy $\left[\mathrm{r}=.893^{*} ; \mathrm{p}=\right.$ $0.001<0.05]$. Thus, the alternate hypothesis which states 
that authority delegation has positive relationship with employee understudy was accepted and the null hypothesis rejected. Al-Jammal, Al- khasawneh, \& Hamadat [3] established that authority delegation positively affects employees' performance.

Hypothesis two was tested with Spearman's correlation coefficient to determine the extent of the relationship between authority delegation and management succession. The result revealed a positive and significant relationship between authority delegation and management succession $\left[\mathrm{r}=.851^{*} ; \mathrm{p}=0.024<0.05\right]$. Bamidele \& Awoyemi [4] established that delegation of responsibility is a vital tool in the hands of leaders in terms of developing the competence level of their subordinates.

Hypothesis three was tested with ordinal logistic regression to ascertain the effect of authority delegation on leadership accountability. The result revealed that authority delegation has positive effect on leadership accountability. ( $\beta$ $=5.006, p=0.008<0.05)$, hence, the acceptance of the alternate hypothesis which states that authority delegation positively affects leadership accountability and the rejection of the null hypothesis. Adiele [1] states that authority delegation showed positive effect on leadership accountability.

\section{Conclusion}

The study concludes that authority delegation is crucial for management and leadership succession. Effective delegation saves manager's valuable time, develops people, grooms successors and motivates subordinates. Delegation of authority plays an important role that grants workers the latitude to develop innovative leadership ideas. Delegated authority allows the superior to share responsibility with his subordinates. It also brings down the excess workload on the superiors, provides opportunities of growth and selfdevelopment to junior executives; create a team of experienced and mature managers for the organization; and develops trust, open communication and engagement among team members.

\section{Recommendations}

The following are the recommendations that were proffered:

Managers and executives need to acquire skills on delegation of authority to enable the leader manage time effectively. Delegation is necessary for both leader and subordinate as it allows the manager have focus on highimpact tasks while the subordinate is empowered by responsibilities that facilitate personal and professional growth.

Organisations should integrate leadership succession programmes in their training plan because it assists in averting the negative operational impact of leadership vacuum. Thus, unplanned succession events, such as resignations or sudden death, can result to loss of a critical dimension or have negative impact on the core values of the organisation.

\section{Limitation of the Study}

The study could have a wider coverage but it was limited to Enugu Electricity Distribution Company (EEDC). There was paucity of data on this topic but this work has provided the necessary information. Future researches should be carried out on authority delegation and employee understudy, authority delegation and management succession and authority delegation and leadership accountability.

\section{Conflict of Interest}

The authors declare that they have no clash of interests.

\section{References}

[1] Adiele B. C (2012) The Impact of Delegation of Authority on Organizational Growth in Nigeria: Case Study of Learn Africa Plc.

[2] Akinfolarin, A. V. (2017). Time management strategies as a panacea for principals' administrative effectiveness in secondary schools in Enugu state, Nigeria. Journal for Studies in Management and Planning 3 (9), 22-31.

[3] Al-Jammal, H. R., Al-Khasawneh, A. L., \& Hamadat, M. H. (2015). The impact of the delegation of authority on employees' performance at great Irbid municipality: case study. International journal of human Resource Studies, 5 (3), 48-69.

[4] Bamidele, O. \& Awoyemi, O. O. (2017). Delegation of responsibilities: A leadership tool for subordinates' competence development in selected academic libraries in Nigeria. International journal of library science, 6 (4), 69-76.

[5] Bolander, P.; Werr, A. \& Asplund, K. (2017). The practice of talent management: A framework and typology, Personnel Review 46 (8) 1523-1551.

[6] Charan, R., Drotter, S., \& Noel, J. (2001). The leadership pipeline: How to build the leadership powered company, San Francisco. G. A: Jossey- Bass.

[7] Dalton, D. R. \& Dalton, C. M. (2007b). CEO succession: Some finer and perhaps provocative points. Journal of Business Strategy, 28 (3) 6-8.

[8] Drucker, P (1974) Management: Tasks, responsibilities, practices. New York: Harper \& Row.

[9] Ezigbo, C. A. (2011). Advanced Management Theory and Applications, Enugu: Immaculate Publications Ltd.

[10] Ezenwakwelu, C. A., Ejim, E. P., \& Adeoye, K. F. (2018). Work place environment management effects on employees' performance in Nigeria Tertiary institutions, International Journal of Management and Economics Invention, 4 (10) 1967-1975.

[11] Garman, A. N., \& Glawe, J. (2004). Succession planning, Consulting Psychology Journal: Practice and Research, 56 (2) 119-128. 
[12] Giambatista, R. C. Rowe, W. G. \& Riaz, S. (2005). Nothing succeeds like succession: A critical review of leader succession literature since 1994. The Leadership Quarterly 16, 97-128.

[13] Gersick, K. E., Lansberg, I., Desjardins, M. \& Dunn, B. (1999). Stages and Transitions: Managing change in the family business. Family Business Review XII (4) 287-297.

[14] Jaques, E (1996), Requisite organization: The total management system. Toronto: Institute.

[15] for Public Administration. Paper presented at the Conference on Effective Organization Design and Managerial Leadership, Radisson Plaza Hotel, Toronto.

[16] Kartz, J. P. (2006). CEO succession: A window on how boards can get it right when choosing a new chief executive, Academy of Management Executive, 14 (2) 130-131.

[17] Kesner, I. F \& Sebora, T. C. (1994). Executive succession: Past, present and future. Journal of Management, 20: 327372.

[18] Koontz, H. \& Weihrich, H. (2003). Management: (9 $9^{\text {th }}$ edition) New York: Mc- Graw Hill Book Company.

[19] Koontz, H. \& Mc- O’Donnell. (2000). Principles and Practice of Management, London: Prentice Hall, Mc-Graw Hill.

[20] Landeta, J., Barrutia, J., \& Hoyos, J. (2009). Management turnover expectations: A variable to explain company readiness to engage continuious management training. International Journal of Human Resource Management 20 (1) 164-185.
[21] Mullins, L. J. (2005). Management and organisational behavior, $\left(7^{\text {th }}\right.$ edition) New York: Prentice Hall.

[22] Osibanjo, O. A., Abiodun, J. A., \& Obamiro, J. K. (2011). Succession planning and organizational survival: Empirical Study of Nigerian private tertiary institutions, Serbian Journal of Management 6 (2) 231-246.

[23] Schall (1997). Public sector succession: A strategic approach to sustaining Innovation. Public Administration Review, 57, 410 .

[24] Sengul, M., Gimeno, J. \& Dial, T. M. (2012). Strategic delegation: A review, theoretical integration, and research agenda. Journal of Management 38 (1) 375-414.

[25] White, R. D. (2010). The micromanagement disease: Symptoms, Diagnosis and cure, Public Personnel Management, 39 (1) 71-76.

[26] Yukl, \& Fu, (1999). Determinants of Delegation and Consultation, Journal of Organisational Behaviour 20 (2) 219-232.

[27] Zald, M. N. (1965). Who shall rule? A political analysis of succession in a large welfare organization. Pacific Sociological Review.

[28] Zhang, Y. \& Rajagopalan, N. (2006). Grooming for the top post and ending the CEO succession crisis. Organisational Dynamics 35 (1) 96-105. 